\title{
Some Properties of Strontium Hydroxide and Its Monohydrate
}

\author{
Elmer T. Carlson
}

\begin{abstract}
Strontium hydroxide, $\mathrm{Sr}(\mathrm{OH})_{2}$, was prepared by hydration of strontium oxide under pressure at $400^{\circ} \mathrm{C}$. The monohydrate was prepared by hydration of the oxide at $168^{\circ} \mathrm{C}$. and also by evaporation of a boiling solution of strontium hydroxide. Opticai properties and $\mathrm{X}$-ray powder diffraction patterns are given.
\end{abstract}

\section{Introduction}

Strontium hydroxide, in the form of its octahydrate, $\mathrm{Sr}(\mathrm{OH})_{2} \cdot 8 \mathrm{H}_{2} \mathrm{O}$, is a substance familiar to the chemist. Various lower hydrates have been postulated from time to time, but there seems to be little evidence of the existence of any except the monohydrate, $\mathrm{Sr}(\mathrm{OH})_{2} \cdot \mathrm{H}_{2} \mathrm{O}$. Dehydration studies by several investigators $[1,2,3]^{1}$ give fairly definite data concerning the dissociation of the octahydrate and of the unhydrated hydroxide.

Equations relating the dissociation pressures of strontium hydroxide and its octahydrate to temperature are given by Tamaru and Siomi [3]. From these equations, the temperature at which the dissociation pressure reaches $760 \mathrm{~mm}$ is calculated to be $92^{\circ} \mathrm{C}$ for $\mathrm{Sr}(\mathrm{OH})_{2} \cdot 8 \mathrm{H}_{2} \mathrm{O}$ and $701^{\circ} \mathrm{C}$ for $\mathrm{Sr}(\mathrm{OH})_{2}$. The shape of the dissociation curve indicates that a monohydrate exists, but its dissociation temperature is not clearly defined.

In view of the amount of work done on $\mathrm{Sr}(\mathrm{OH})_{2}$ and its monohydrate, it is somewhat surprising that there appears to be no published data on the optical properties of these compounds. X-ray diffraction patterns were published by Hüttig and Arbes [1], but in such form that they are very difficult to translate in terms of interplanar spacings, or even to use as a basis for identification.

In connection with some hydrothermal studies of strontium compounds, it was necessary to be able to identify the various forms of the hydroxide. Accordingly, the hydroxide and its monohydrate were prepared, and their more useful identifying properties determined.

\section{Procedure and Results}

Strontium carbonate, reagent grade, was heated at $1,300^{\circ} \mathrm{C}$ to convert it to the oxide. The dry oxide was then exposed to water vapor in a pressure bomb at $400^{\circ} \mathrm{C}$ for 3 days. The product was a dry powder containing 0.98 mole of water per mole of $\mathrm{SrO}$, closely approximating the composition of

Figures in brackets indicate literature references at the end of this paper.
$\mathrm{Sr}(\mathrm{OH})_{2}$. The crystals averaged about $20 \mu$ in diameter, but were somewhat rounded and irregular, so that the ideal shape could not be determined. They appeared to be in the form of relatively thick plates. The crystals described were prepared with a moderate excess of water in the bomb. Reducing the water to the stoichiometric quantity resulted in crystals that were much smaller but of the same composition. The optical properties are as follows: Refractive indices, $\alpha=1.588, \beta=1.599$, and $\gamma=1.610$; character, biaxial; sign, positive; and optic axial angle $2 \mathrm{~V}$, nearly $90^{\circ}$.

Hydrothermal treatment of strontium oxide at $168^{\circ} \mathrm{C}$, in the presence of a slight excess of water, resulted in a product having 1.95 moles of $\mathrm{H}_{2} \mathrm{O}$ per mole of $\mathrm{SrO}$, approximately the composition of $\mathrm{Sr}(\mathrm{OH})_{2} \cdot \mathrm{H}_{2} \mathrm{O}$. The crystals were larger than those described above but quite irregular in shape. The indices are $\alpha=1.570, \quad \beta=1.589, \quad$ and $\gamma=1.610$; character, biaxial; sign, positive; and $2 \mathrm{~V}$ nearly $90^{\circ}$. The similarity in optical properties points to a close relationship between the hydroxide and its monohydrate, which is borne out by the similarity of the X-ray patterns.

The monohydrate was also obtained by slow evaporation of a saturated solution of strontium hydroxide at the boiling point. Many of the larger crystals were in the form of hexagonal prisms, although it is evident from the optical properties that the symmetry cannot be truly hexagonal. The preparation, when dried at $110^{\circ} \mathrm{C}$, lost weight equivalent to 1.23 moles of water. At $900^{\circ} \mathrm{C}$ it lost an additional 1.02 moles, corresponding to conversion to $\mathrm{SrO}$. The loss at $110^{\circ} \mathrm{C}$ is evidently due to the expulsion of the 1 molecule of water of hydration, the small excess presumably resulting either from entrapped moisture or from the presence of a small amount of the octahydrate. Most of the precipitated hydroxide adhered tenaciously to the flask, and there was microscopic evidence of reaction with the glass, with the formation of minute crystals of strontium silicate hydrate $\left(3 \mathrm{SrO} \cdot 2 \mathrm{SiO}_{2} \cdot 4 \mathrm{H}_{2} \mathrm{O}\right)$ [4]. The fact that strontium hydroxide monohydrate is formed under these conditions indicates that it is the stable phase at the boiling point. 
TABLE 1. Interplanar spacings and relative intensities of $X$-ray diffraction lines for strontium hydroxide and its monohydrate

\begin{tabular}{|c|c|c|c|}
\hline \multicolumn{2}{|c|}{$\mathrm{Sr}(\mathrm{OH})_{2}$} & \multicolumn{2}{|c|}{$\mathrm{Sr}(\mathrm{OH})_{2} \cdot \mathrm{H}_{2} \mathrm{O}$} \\
\hline$d$ & I & $d$ & $I$ \\
\hline$A$ & & A & \\
\hline 6. 21 & 17 & 6.18 & 100 \\
\hline 5. 21 & 80 & 4. 54 & 95 \\
\hline 4. 95 & 25 & 3.65 & 25 \\
\hline $\begin{array}{l}4.56 \\
4.14\end{array}$ & 14 & $\begin{array}{l}3.36 \\
3\end{array}$ & 44 \\
\hline $\begin{array}{l}4.14 \\
3.847\end{array}$ & $\begin{array}{r}3 \\
55\end{array}$ & $\begin{array}{l}3.14 \\
2.95\end{array}$ & $\begin{array}{r}60 \\
7\end{array}$ \\
\hline 3. 651 & $\begin{array}{r}50 \\
7\end{array}$ & $\begin{array}{l}2.95 \\
2.84\end{array}$ & 35 \\
\hline 3. 358 & $\begin{array}{r}7 \\
38\end{array}$ & $\begin{array}{l}2.81 \\
2.47\end{array}$ & $\begin{array}{r}78 \\
30\end{array}$ \\
\hline $\begin{array}{l}\begin{array}{l}3.302 \\
3.132\end{array} \\
\text { - }\end{array}$ & $\begin{array}{r}38 \\
100\end{array}$ & $\begin{array}{l}2.47 \\
2.36\end{array}$ & $\begin{array}{l}30 \\
8\end{array}$ \\
\hline 3.073 & 23 & 2. 29 & 50 \\
\hline 2. 922 & 30 & 2. 23 & 80 \\
\hline 2.903 & 58 & 2.10 & 14 \\
\hline 2.848 & 5 & 2.07 & 14 \\
\hline 2.815 & 8 & 1. 974 & 18 \\
\hline 2.747 & 10 & 1. 824 & 23 \\
\hline 2. 602 & 4 & 1.815 & 7 \\
\hline 2.473 & 35 & 1.798 & 4 \\
\hline 2. 343 & 62 & 1.760 & 10 \\
\hline 2. 294 & 24 & 1.750 & 8 \\
\hline 2. 168 & 16 & 1.737 & 6 \\
\hline 2. 107 & 3 & 1. 693 & 8 \\
\hline 2. 093 & 28 & 1.678 & 7 \\
\hline 1. 978 & 7 & 1.625 & 15 \\
\hline 1.960 & 27 & 1.603 & 7 \\
\hline 1. 947 & 60 & 1.585 & 7 \\
\hline 1. 887 & 25 & 1. 549 & 12 \\
\hline 1. 835 & 5 & 1. 531 & 12 \\
\hline $\begin{array}{l}1.823 \\
\text { S }\end{array}$ & 3 & $\begin{array}{l}1.518 \\
\text {. }\end{array}$ & 6 \\
\hline 1.810 & 18 & 1.510 & 2 \\
\hline 1. 746 & 9 & 1. 481 & 7 \\
\hline 1. 697 & 24 & $\begin{array}{l}1.426 \\
\text {. }\end{array}$ & 4 \\
\hline 1. 661 & 9 & 1. 407 & 8 \\
\hline 1. 649 & 9 & 1. 378 & 8 \\
\hline 1. 624 & 17 & $\begin{array}{l}\text { 1. } 368 \\
\text { lo }\end{array}$ & 2 \\
\hline 1. 574 & 7 & 1. 340 & 6 \\
\hline 1. 535 & 10 & 1.313 & 10 \\
\hline 1. 530 & 11 & 1. 303 & 2 \\
\hline 1. 512 & 5 & 1. 287 & 6 \\
\hline 1. 4942 & 4 & 1. 267 & 4 \\
\hline 1. 4895 & 3 & 1. 235 & 13 \\
\hline $\begin{array}{l}\text { 1. } 4742 \\
\text { lat }\end{array}$ & 4 & $\begin{array}{l}\text { 1. } 227 \\
\text { l }\end{array}$ & 4 \\
\hline 1. 4600 & 9 & 1. 219 & 2 \\
\hline 1. 3764 & 3 & 1. 211 & 2 \\
\hline 1. 3585 & 10 & & \\
\hline 1. 3076 & 5 & & \\
\hline $\begin{array}{l}\text { 1. } 2825 \\
\text { 1. } 2664\end{array}$ & $\begin{array}{l}7 \\
8\end{array}$ & & \\
\hline $\begin{array}{l}\text { 1. } 2344 \\
\text { 1. } 2343\end{array}$ & 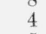 & & \\
\hline 1. 2268 & 5 & & \\
\hline 1. 2187 & 11 & & \\
\hline 1. 2065 & 4 & & \\
\hline 1. 1969 & 3 & & \\
\hline 1. 1794 & 6 & & \\
\hline 1. 1603 & 6 & & \\
\hline $\begin{array}{l}\text { 1. } 1288 \\
1.1000\end{array}$ & $\begin{array}{l}7 \\
3\end{array}$ & & \\
\hline 1. 0731 & 3 & & \\
\hline 1. 0567 & 3 & 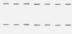 & \\
\hline 1. 0297 & 3 & & \\
\hline 1. 0055 & 3 & & \\
\hline
\end{tabular}

X-ray powder diffraction patterns for the two compounds are given in table 1 . These were made with an X-ray Geiger-counter diffractometer, using copper $\mathrm{K} \alpha$ radiation. It may be noted that the two patterns are quite similar, especially in the size of the larger spacings.

\section{Summary}

Strontium hydroxide and its monohydrate have been prepared, and their optical properties determined. The refractive indices are: for $\mathrm{Sr}(\mathrm{OH})_{2}$, $\alpha=1.588, \beta=1.599$, and $\gamma=1.610$; for $\mathrm{Sr}(\mathrm{OH})_{2} \cdot \mathrm{H}_{2} \mathrm{O}$, $\alpha=1.570, \beta=1.589$, and $\gamma=1.610$. Both are biaxial, positive, with $2 \mathrm{~V}$ near $90^{\circ}$. X-ray diffraction patterns are given.

The author acknowledges with thanks the assistance of G. M. Ugrinic, who prepared the X-ray patterns, and A. Van Valkenburg, who checked the refractive indices.

\section{References}

[1] G. F. Hüttig and A. Arbes, Z. anorg. u. allgem. Chem, 192, 225 (1930).

[2] C. Nogareda, Rev. acad. cienc. exact., fís.-quím. y nat. Madrid 26, 315 (1931); Chem. Abstr. 26, 1869 (1932).

[3] S. Tamaru and K. Siomi, Z. physik Chem. [A] 171, 221, 229 (1934).

[4] E. T. Carlson and L. S. Wells, J. Research NBS 51, 73 (1953) RP2433.

Washington, August 30, 1954. 